\title{
Department of Education Internet Connectivity Project Number 50, s.2009 in the Utilization of Edmodo in Social Studies Lesson in Secondary Schools of Gingoog City, Misamis Oriental and Cagayan de Oro City, Philippines
}

\author{
Ma. Theresa J. Macasukit-Morales, Victoria O. Sumanpan \\ mtjmacasukit030886@gmail.com,vos1223@gmail.com
}

University of Science and Technology of Southern Philippines, Lapasan Cagayan de Oro City, 9000, Philippines

Gingoog City Comprehensive National High School, Gingoog City, 9014, Philippines

\begin{abstract}
The study aimed to assess and analyze the provisions stipulated in DepEd Order no.50, s.2009, or the Department of Education Internet Connectivity Project (DICP), to be implemented in secondary public and private schools of Gingoog City with regards to the application of the Edmodo platform.

This study was anchored on the theory of Rogers (1962) which is Diffusion of Innovation Theory in Modern Education, and expanded by Stukalenko (2016) in the field of education.

This study aimed to analyze the implementation of DICP in the secondary public and private schools of Gingoog City. Furthermore, the study targeted to evaluate the use of Edmodo platform in the teaching of Social Studies for Grades 8 and 9.

The researcher utilized a descriptive research design which aimed to assess the provisions of DICP, as stipulated in the DepED Order n.50, s.2009. It is used to evaluate how Grades 8 and 9 students of selected schools in Gingoog City, Misamis Oriental, and Cagayan de Oro City assessed the provisions of DICP on the use of Edmodo online networking application in daily classroom instruction.

Results revealed that the relationship between the school facilities, and the teachers' competencies in teaching Edmodo platform contributed to academic performance. All these were contributors to the effective implementation of DICP

The results implied that students when exposed to Edmodo have a higher achievement test scores in social studies. With this, the integration of Edmodo platform can improve the achievement level in social studies classes.
\end{abstract}

Keywords: internet connectivity, edmodo, dicp, social studies 


\section{Introduction}

Educators believed that using technology can be an effective factor in education for the new generation making education goals easier to achieve. It becomes an integral part of people's lives and the common ground for many high school students and its use has the potential impact to learning. Using multimedia tools gives students the opportunity to participate and interact in the classroom.

The implementation of technology into the classroom is timely and has been increasingly integrated throughout both the K-12 and higher education experience and curriculum. In fact, the Department of Education launched the DepEd Internet Connectivity Project (DICP), pursuant to DepEd Order no.50, s.2009, in line with the Presidential Directives to provide Public Secondary Schools with internet access.

It has been observed and experienced that teachers are bombarded with many tasks in school aside from the preparation of instructional materials and the making of daily lesson plans, making work laborious. With these voluminous tasks and in the advent of computer technology, teachers have the discretion to use the fastest and easiest way in delivering the best pedagogy to in order to meet the demands of the $21^{\text {st }}$ century learners.

Problem 1. What is the extent of DICP implementation in terms of:

1. Internet connectivity;

2. School facilities;

3. Computer Laboratories;

4. Computer Hardware;

5. Computer Software; and,

6. Computer student ratio.

Effective implementation of the DICP needs the availability of certain indicators to ensure its correlation to the usage of the Edmodo platform by select teachers teaching Social Studies. These six (6) indicators were then utilized by the researcher to identify the status of the DICP implementation in the targeted secondary schools. The table below showed the extent of the DICP implementation in the targeted schools.

Table 1. Extent of the DICP implementation

\begin{tabular}{|c|c|c|c|c|c|}
\hline & $\begin{array}{c}\text { Fully } \\
\text { Implemented }\end{array}$ & $\begin{array}{c}\text { Often } \\
\text { Implemented }\end{array}$ & $\begin{array}{l}\text { Moderately } \\
\text { implemented }\end{array}$ & $\begin{array}{c}\text { Sometimes } \\
\text { Implemented }\end{array}$ & $\begin{array}{c}\text { Never } \\
\text { Implemented }\end{array}$ \\
\hline $\begin{array}{l}\text { 1. Facilitates the process of } \\
\text { internet connectivity }\end{array}$ & $16(100 \%)$ & 0 & 0 & 0 & 0 \\
\hline $\begin{array}{l}\text { 2. Has ICT coordinator and } \\
\text { computer literate teacher }\end{array}$ & $16(100 \%)$ & 0 & 0 & 0 & 0 \\
\hline $\begin{array}{l}\text { 3. Submits monthly report or } \\
\text { quarterly reports to the } \\
\text { central office for utilization }\end{array}$ & $16(100 \%)$ & 0 & 0 & 0 & 0 \\
\hline $\begin{array}{l}\text { 3. Assists the school in } \\
\text { canvassing/shopping } \\
\text { whether implementing/non } \\
\text { implementing units }\end{array}$ & $10(62.5 \%)$ & $6(37.5 \%)$ & 0 & 0 & 0 \\
\hline $\begin{array}{l}\text { 4. Facilitates the payment of } \\
\text { internet subscription fee }\end{array}$ & $16(100 \%)$ & 0 & 0 & 0 & 0 \\
\hline 5. Has an IT expert to & $14(87.5 \%)$ & $2(12.5 \%)$ & 0 & 0 & 0 \\
\hline
\end{tabular}


troubleshoot the computer

6. Receives an installation fee

16(100\%)

and internet service fee

0

0

0

0

7. Computer laboratories are connected to a local Network $9(56.25 \%) \quad 5(31.25 \%)$

$2(12.5 \%)$

0

0

(LAN)

8. Ensures one-on-one handson computer $5(31.25 \%)$ $8(50 \%)$

$3(18.75 \%)$

0

0

9. Accommodates all the students for internet $14(87.5 \%)$ $2(12.5 \%)$

0

0

0 utilization

10. Subscribes the internet connectivity a year round

11. Assures computer laboratory rooms are $14(87.5 \%) \quad 2(12.5 \%)$ 0 0 ventilated and airconditioned

\section{Liquidates internet} subscription promptly $16(100 \%)$ 0 0 0 0

13. Monitors the maximum

The results indicated that all indicators of DICP implementation are significantly correlated to the usage of Edmodo Platform in teaching Social Studies. As shown, the computer laboratories indicator $(0.411$, $p<0.05)$ has the highest correlation, followed by the computer ratio indicator $(3.93, p<0.05)$.

Furthermore, the indicators are revealed to have a positive correlation to the use of Edmodo in teaching Social Studies. Starting from the computer hardware indicator $(0.380, p<0.05)$, internet connectivity indicator $(0.380, p<0.05)$, school facilities indicator $(0.336, p<0.05)$, and computer software indicator $(0.239$, $p<0.05)$. Therefore, the overall DICP implementation is positively and moderately correlated to the use of Edmodo platform in teaching Social Studies.

Problem 2. What is the competency level of the teachers trained in Edmodo?

Another domain to be considered to have an effective DICP implementation is to assess the competency level of teachers trained in the usage of the Edmodo platform. Like all types of technological advances and innovation, the effectiveness relies on the user. The table below showed the competency level of teachers in using the Edmodo platform in teaching lessons in Social Studies.

Table 2. Competency Level of Teachers in Edmodo

\begin{tabular}{lcccc}
\hline & Unsatisfactory & Satisfactory & Very Satisfactory & Outstanding \\
\hline TASK (Focus on the Teacher's Actions) & 0 & 0 & $27(90 \%)$ & $3(10 \%)$ \\
\hline Teacher's Competence & 0 & 0 & $30(100 \%)$ & 0 \\
\hline $\begin{array}{l}\text { Lesson Establishment/ } \\
\text { Development }\end{array}$ & & & & \\
\hline
\end{tabular}




\begin{tabular}{|c|c|c|c|c|}
\hline Interaction or Discussion & 0 & 0 & $27(90 \%)$ & $3(10 \%)$ \\
\hline $\begin{array}{l}\text { Instructional models and } \\
\text { strategies }\end{array}$ & 0 & 0 & $21(70 \%)$ & $9(30 \%)$ \\
\hline Enrichment (Application) & 0 & 0 & $21(70 \%)$ & $9(30 \%)$ \\
\hline \multicolumn{5}{|c|}{ ACTION (Focus and observe closely to the learners actions) } \\
\hline Student/Class & 0 & 0 & $21(70 \%)$ & $9(30 \%)$ \\
\hline \multicolumn{5}{|l|}{ Engagement } \\
\hline $\begin{array}{l}\text { Response (Quality of } \\
\text { Answer) }\end{array}$ & 0 & 0 & $27(90 \%)$ & $3(10 \%)$ \\
\hline Outputs (Quality of Work) & 0 & 0 & $27(90 \%)$ & $3(10 \%)$ \\
\hline \multicolumn{5}{|c|}{ RESULT (Focus on the end results or outcomes) } \\
\hline Outcomes (Evaluation) & 0 & 0 & $26(86 \%)$ & $4(14 \%)$ \\
\hline $\begin{array}{l}\text { Assessment of Learning } \\
\text { (Reflection) }\end{array}$ & 0 & 0 & $24(80 \%)$ & $6(20 \%)$ \\
\hline
\end{tabular}

The results showed that in all three main indicators - Task, Action, and Result - the respondents are in the Very Satisfactory level of competency in the utilization of the Edmodo platform in teaching lessons in Social Studies.

With this level of competency, there is a positive result of the DICP implementation in the respective schools of the respondents.

Problem 3. What is the result of the achievement test of the students in Social Studies using the Edmodo platform?

Students' knowledge is mostly measured through various assessments. Common assessment is the administering of achievement tests to students in schools. With the advent of various technological tools, teachers have a wide array of delivering lessons suited to the students' need to meet academic assessments. The table shows the mean results of achievement tests of students in Social Studies before and after the usage of the Edmodo platform.

Table 3.1. Mean Level of Respondents' Achievement Test in Social Studies 8 Using Edmodo Platform Control Without Edmodo Experimental with Edmodo

\begin{tabular}{lclllllll}
\multicolumn{1}{c}{ Grade 8 } & Pre & Level & Post & Level & Pre & Level & Post & $\begin{array}{c}\text { Level of } \\
\text { Achievement }\end{array}$ \\
\cline { 2 - 9 } & & & & & & & & \\
\hline $\begin{array}{l}\text { Anakan NHS } \\
\text { 8 }\end{array}$ & 7.74 & Fair & 13.34 & Good & 7.914 & Fair & 18.67 & Excellent \\
\hline GCCNHS 8 & 7.34 & Fair & 14.27 & Good & 7.67 & Fair & 17.89 & Excellent \\
\hline JMNHS 8 & 6.89 & Fair & 13.8 & Good & 7.89 & Fair & 16.89 & Excellent \\
\hline Lunao 8 & 7.35 & Fair & 14.57 & Good & 7.34 & Fair & 18.56 & Excellent \\
\hline Pundasan 8 & 7.34 & Fair & 14.78 & Good & 7.35 & Fair & 18.26 & Excellent \\
\hline San Luis 8 & 7.16 & Fair & 15.34 & Good & 7.76 & Fair & 18.34 & Excellent \\
\hline Talisayan 8 & 7.12 & Fair & 14.78 & Good & 7.09 & Fair & 18.12 & Excellent \\
\hline Medina 8 & 7.15 & Fair & 13.16 & Good & 7.24 & Fair & 18.34 & Excellent \\
\hline $\begin{array}{l}\text { Sugbong } \\
\text { Cogon 8 }\end{array}$ & 6.45 & Fair & 12.67 & Good & 6.53 & Fair & 15.67 & Excellent \\
\hline
\end{tabular}




\begin{tabular}{lclllllll}
\hline Baliwagan 8 & 6.34 & Fair & 13.15 & Good & 6.37 & Fair & 16.01 & Excellent \\
\hline Sta. Ana 8 & 7.34 & Fair & 16.23 & Good & 7.13 & Fair & 17.6 & Excellent \\
\hline Alubijid 8 & 6.45 & Fair & 13.29 & Good & 6.56 & Fair & 17.89 & Excellent \\
\hline Naawan 8 & 6.89 & Fair & 14.67 & Good & 6.78 & Fair & 17.34 & Excellent \\
\hline Bulua 8 & 7.89 & Fair & 14.54 & Good & 7.96 & Fair & 16.78 & Excellent \\
\hline Macabalan 8 & 7.38 & Fair & 14.23 & Good & 7.23 & Fair & 15.67 & Excellent \\
\hline Overall Mean & $\mathbf{7 . 1 2 2}$ & Fair & $\mathbf{1 4 . 1 8 8}$ & Good & $\mathbf{7 . 2 5 4 2 6 7}$ & Fair & $\mathbf{1 7 . 4 6 8 6 7}$ & Excellent \\
\hline
\end{tabular}

Legend: 4.50-5.00, Outstanding (O); 3.50-4.49, Very Satisfactory (VS); 2.50-3.49, Satisfactory (S); 1.50-2.49, Fairly satisfactory (FS); 1.49 -below, Did not meet expectations

The results above showed that though both the overall mean level of the respondents' preachievement test scores were Fair, the Experimental with Edmodo indicator has a slightly higher value (7.254) compared to the Control without Edmodo indicator (7.122). Additionally, the overall mean level of the respondents' post-achievement test results in the Experimental with Edmodo indicator was higher (17.469 Excellent) as to that of the Control without Edmodo indicator $(14.188$ - Good).

Table 3.2. Mean Level of Respondents' Achievement Test in Social Studies 9 Using Edmodo Platform

Grade 9 Control Without Edmodo Experimental with Edmodo

\begin{tabular}{lcccccccc} 
& Pre & Level & Post & Level & Pre & Level & Post & $\begin{array}{l}\text { Level of } \\
\text { Achievement }\end{array}$ \\
\hline $\begin{array}{l}\text { Anakan NHS } \\
\text { 9 }\end{array}$ & 8.65 & Fair & 14.34 & Good & 7.57 & Fair & 19.23 & Excellent \\
\hline GCCNHS 9 & 7.89 & Fair & 15.28 & Good & 7.7 & Fair & 18.34 & Excellent \\
\hline JMNHS 9 & 7.56 & Fair & 16.56 & Good & 7.67 & Fair & 18.69 & Excellent \\
\hline Lunao 9 & 8.24 & Fair & 15.28 & Good & 8.87 & Fair & 17.78 & Excellent \\
\hline Pundasa 9 & 7.14 & Fair & 16.15 & Good & 7.54 & Fair & 18.32 & Excellent \\
\hline San Luis 9 & 7.25 & Fair & 16.78 & Good & 7.13 & Fair & 18.23 & Excellent \\
\hline Talisayan 9 & 7.78 & Fair & 16.31 & Good & 8.12 & Fair & 18.05 & Excellent \\
\hline Medina 9 & 7.89 & Fair & 14.56 & Good & 7.96 & Fair & 18.45 & Excellent \\
\hline $\begin{array}{l}\text { Sugbong } \\
\text { Cogon 9 }\end{array}$ & 7.8 & Fair & 15.23 & Good & 7.6 & Fair & 15.45 & Excellent \\
\hline Baliwagan9 & 7.6 & Fair & 15.23 & Good & 7.8 & Fair & 17.45 & Excellent \\
\hline Sta. Ana 9 & 6.78 & Fair & 14.24 & Good & 6.59 & Fair & 18.34 & Excellent \\
\hline Alubijid 9 & 6.89 & Fair & 15.34 & Good & 6.78 & Fair & 18.45 & Excellent \\
\hline Naawan 9 & 8.45 & Fair & 15.65 & Good & 7.45 & Fair & 16.13 & Excellent \\
\hline Bulua 9 & 6.45 & Fair & 16.65 & Good & 6.3 & Fair & 17.12 & Excellent \\
\hline Macasandig 9 & 8.43 & Fair & 16.76 & Good & 8.26 & Fair & 16.13 & Excellent \\
\hline Overall Mean & $\mathbf{7 . 6 5 3}$ & Fair & $\mathbf{1 5 . 6 2 4}$ & Good & $\mathbf{7 . 5 5 6}$ & Fair & $\mathbf{1 7 . 7 4 4}$ & Excellent \\
\hline
\end{tabular}

Legend: 4.50-5.00, Outstanding (O); 3.50-4.49, Very Satisfactory (VS); 2.50-3.49, Satisfactory $(S) ; 1.50$ 2.49, Fairly satisfactory (FS); 1.49 -below, Did not meet expectations

The results above showed that even if both the overall mean level of the respondents' preachievement test scores were Fair, the Control without Edmodo indicator has a slightly higher value (7.653) compared to the Experimental with Edmodo indicator (7.556). Additionally, the overall mean level of the respondents' post-achievement test results in the Experimental with Edmodo indicator was higher (17.744 - 
Excellent) as to that of the Control without Edmodo indicator (15.624 - Good).

The results imply that there were higher achievement test results in Social Studies when respondents were exposed to the Edmodo platform, as compared to when the respondents were unexposed yet of the Edmodo platform. With this, it is implied that the integration of Edmodo platform can improve the achievement level of students in their Social Studies classes.

Problem 4. What are the problems encountered in the implementation of the DICP?

Similar to any related action, the implementation of the DICP is bound to have its share of complications. However, these complications could provide enhancements to the DICP implementation to further its effectiveness. The tables below show the categories of concepts of the respondents' problems encountered in the DICP implementation, the concepts derived from the respondents' transcripts on their problems encountered in the DICP implementation, and the themes based on the concepts constructed from the respondents' problems encountered in the DICP implementation, consecutively.

Table 4.1. Categories of the Concepts of the Problems Encountered by the Respondents in the Implementation of DICP

\begin{tabular}{|c|c|c|}
\hline $\begin{array}{l}\text { REFERENCE } \\
\text { NUMBERS }\end{array}$ & CONCEPTS & CATEGORIES \\
\hline $\mathbf{1 A}$ & $\begin{array}{l}\text { The school experienced poor connectivity } \\
\text { encounter issues. }\end{array}$ & Problems of Internet Connectivity \\
\hline 1B & $\begin{array}{l}\text { Additional functional computer in the } \\
\text { school. }\end{array}$ & $\begin{array}{l}\text { Ratio on Functional Computer } \\
\text { Availability for Students }\end{array}$ \\
\hline 1C & The school should have skilled IT. & $\begin{array}{l}\text { Hired Skilled Computer Trouble } \\
\text { Shooter }\end{array}$ \\
\hline $2 \mathrm{~A}$ & $\begin{array}{l}\text { We experienced problem on inconsistent } \\
\text { connectivity. }\end{array}$ & Problems of Internet Connectivity \\
\hline 2B & $\begin{array}{l}\text { The school need more functional } \\
\text { computers. }\end{array}$ & $\begin{array}{l}\text { Ratio on Functional Computer } \\
\text { Availability for Students }\end{array}$ \\
\hline 2C & Expert IT for trouble shooting of computer. & $\begin{array}{l}\text { Hired Skilled Computer Trouble } \\
\text { Shooter }\end{array}$ \\
\hline 3A & $\begin{array}{l}\text { The teachers and students experienced } \\
\text { noticeable delays of usability. }\end{array}$ & Problems of Internet Connectivity \\
\hline 3B & $\begin{array}{l}\text { The school should have safe computer } \\
\text { laboratory. }\end{array}$ & $\begin{array}{l}\text { Ratio on Functional Computer } \\
\text { Availability for Students }\end{array}$ \\
\hline 3C & There should have IT in the school. & $\begin{array}{l}\text { Hired Skilled Computer Trouble } \\
\text { Shooter }\end{array}$ \\
\hline 4A & It happened to have limited connectivity. & Problems of Internet Connectivity \\
\hline 4B & $\begin{array}{l}\text { The school need to consider the ratio of the } \\
\text { computers. }\end{array}$ & $\begin{array}{l}\text { Ratio on Functional Computer } \\
\text { Availability for Students }\end{array}$ \\
\hline 4C & IT assistance for the program. & $\begin{array}{l}\text { Hired Skilled Computer Trouble } \\
\text { Shooter }\end{array}$ \\
\hline 5A & $\begin{array}{l}\text { Limited quality service of server in the } \\
\text { school. }\end{array}$ & Problems of Internet Connectivity \\
\hline 5B & We need to take good care the computer. & $\begin{array}{l}\text { Ratio on Functional Computer } \\
\text { Availability for Students }\end{array}$ \\
\hline 5C & IT in-charge in the computer laboratory. & $\begin{array}{l}\text { Hired Skilled Computer Trouble } \\
\text { Shooter }\end{array}$ \\
\hline 6A & We have weak internet connection. & Problems of Internet Connectivity. \\
\hline
\end{tabular}




\begin{tabular}{|c|c|c|}
\hline 6B & $\begin{array}{l}\text { We need to assigned computer each } \\
\text { students. }\end{array}$ & $\begin{array}{l}\text { Ratio on Functional Computer } \\
\text { Availability for Students }\end{array}$ \\
\hline 6C & Availability of computer laboratory. & $\begin{array}{l}\text { Hired Skilled Computer Trouble } \\
\text { Shooter }\end{array}$ \\
\hline 7A & $\begin{array}{l}\text { We have experienced failing to receive } \\
\text { internet data. }\end{array}$ & Problems of Internet Connectivity. \\
\hline 7B & $\begin{array}{l}\text { We need to have proper tracking of } \\
\text { computer. }\end{array}$ & $\begin{array}{l}\text { Ratio on Functional Computer } \\
\text { Availability for Students }\end{array}$ \\
\hline 7C & $\begin{array}{l}\text { IT Assistance for the program } \\
\text { implementation. }\end{array}$ & $\begin{array}{l}\text { Hired Skilled Computer Trouble } \\
\text { Shooter }\end{array}$ \\
\hline $\mathbf{8 A}$ & $\begin{array}{l}\text { We need huge demand for high speed } \\
\text { internet connection. }\end{array}$ & Problems of Internet Connectivity. \\
\hline $\mathbf{8 B}$ & $\begin{array}{l}\text { We need to input the activities in the } \\
\text { computer. }\end{array}$ & $\begin{array}{l}\text { Ratio on Functional Computer } \\
\text { Availability for Students }\end{array}$ \\
\hline 8C & School should have computer expert. & $\begin{array}{l}\text { Hired Skilled Computer Trouble } \\
\text { Shooter }\end{array}$ \\
\hline 9A & We need reliable internet service provider. & Problems of Internet Connectivity. \\
\hline 9B & $\begin{array}{l}\text { The discussion should be available in the } \\
\text { computer. }\end{array}$ & $\begin{array}{l}\text { Ratio on Functional Computer } \\
\text { Availability for Students }\end{array}$ \\
\hline 9C & $\begin{array}{l}\text { Considered the availability of computer } \\
\text { expert. }\end{array}$ & $\begin{array}{l}\text { Hired Skilled Computer Trouble } \\
\text { Shooter }\end{array}$ \\
\hline 10A & $\begin{array}{l}\text { We experienced temporary congestion at } \\
\text { times leading to connection problems. }\end{array}$ & Problems of Internet Connectivity \\
\hline 10B & $\begin{array}{l}\text { Inputs of the platforms should be in the } \\
\text { computer. }\end{array}$ & $\begin{array}{l}\text { Ratio on Functional Computer } \\
\text { Availability for Students }\end{array}$ \\
\hline 10C & The presence of the IT expert. & $\begin{array}{l}\text { Hired Skilled Computer Trouble } \\
\text { Shooter }\end{array}$ \\
\hline 11A & We have inconsistent internet connectivity. & Problems of Internet Connectivity \\
\hline 11B & $\begin{array}{l}\text { The students should have no problem on } \\
\text { computer availability. }\end{array}$ & $\begin{array}{l}\text { Ratio on Functional Computer } \\
\text { Availability for Students }\end{array}$ \\
\hline 11C & Hired IT expert. & $\begin{array}{l}\text { Hired Skilled Computer Trouble } \\
\text { Shooter }\end{array}$ \\
\hline 12A & $\begin{array}{l}\text { Not reliable internet service provider in the } \\
\text { school. }\end{array}$ & Problems of Internet Connectivity \\
\hline 12B & $\begin{array}{l}\text { The teachers should have each computer for } \\
\text { the platform. }\end{array}$ & $\begin{array}{l}\text { Ratio on Functional Computer } \\
\text { Availability for Students }\end{array}$ \\
\hline 12C & Availability of computer in-charge. & $\begin{array}{l}\text { Hired Skilled Computer Trouble } \\
\text { Shooter }\end{array}$ \\
\hline 13A & Failing internet connectivity in the school. & Problems of Internet Connectivity \\
\hline 13B & $\begin{array}{l}\text { The availability of functional computer } \\
\text { laboratory. }\end{array}$ & $\begin{array}{l}\text { Ratio on Functional Computer } \\
\text { Availability for Students }\end{array}$ \\
\hline 13C & Functional computer laboratory. & $\begin{array}{l}\text { Hired Skilled Computer Trouble } \\
\text { Shooter }\end{array}$ \\
\hline 14A & $\begin{array}{l}\text { Inconsistent internet connectivity in the } \\
\text { school. }\end{array}$ & Problems of Internet Connectivity \\
\hline 14B & $\begin{array}{l}\text { The availability of functional computer for } \\
\text { the students. }\end{array}$ & $\begin{array}{l}\text { Ratio on Functional Computer } \\
\text { Availability for Students }\end{array}$ \\
\hline $14 \mathrm{C}$ & The presence of computer expert. & $\begin{array}{l}\text { Hired Skilled Computer Trouble } \\
\text { Shooter }\end{array}$ \\
\hline
\end{tabular}




\begin{tabular}{cll}
\hline 15A & $\begin{array}{l}\text { Weak quality of service connectivity in the } \\
\text { school. }\end{array}$ & Problems of Internet Connectivity \\
\hline 15B & $\begin{array}{l}\text { The teacher should have functional } \\
\text { computer anytime needed. }\end{array}$ & $\begin{array}{l}\text { Ratio on Functional Computer } \\
\text { Availability for Students }\end{array}$ \\
\hline 15C & $\begin{array}{l}\text { The presence of IT expert in computer } \\
\text { laboratory. }\end{array}$ & $\begin{array}{l}\text { Hired Skilled Computer Trouble } \\
\text { Shooter }\end{array}$ \\
\hline 16A & $\begin{array}{l}\text { Poor connectivity of internet service in the } \\
\text { school. }\end{array}$ & Problems of Internet Connectivity \\
\hline 16B & $\begin{array}{l}\text { The students' ratio on computer availability } \\
\text { should be considered. }\end{array}$ & $\begin{array}{l}\text { Ratio on Functional Computer } \\
\text { Availability for Students }\end{array}$ \\
\hline ThC & The presence of IT expert for the platform. & $\begin{array}{l}\text { Hired Skilled Computer Trouble } \\
\text { Shooter }\end{array}$ \\
\hline
\end{tabular}

Table 4.2. Concepts Derived from the Transcripts of Problems Encountered by the Respondents in the Implementation of DICP

\begin{tabular}{|c|c|c|}
\hline $\begin{array}{l}\text { REFERENCE } \\
\text { NUMBERS }\end{array}$ & $\begin{array}{l}\text { TRANSFORMED MEANING } \\
\text { UNITS }\end{array}$ & CONCEPTS \\
\hline $\mathbf{1 A}$ & $\begin{array}{l}1 \text { Experience problems on internet } \\
\text { connectivity. }\end{array}$ & $\begin{array}{l}\text { The school experienced poor connectivity } \\
\text { encounter issues. }\end{array}$ \\
\hline $\mathbf{2 A}$ & $\begin{array}{l}2 \text { Issues on inconsistent connectivity of } \\
\text { internet. }\end{array}$ & $\begin{array}{l}\text { We experienced problem on inconsistent } \\
\text { connectivity. }\end{array}$ \\
\hline $\mathbf{3 A}$ & $\begin{array}{l}3 \text { Encounter issues on delays of internet } \\
\text { usability. }\end{array}$ & $\begin{array}{l}\text { The teachers and students experienced } \\
\text { noticeable delays of usability. }\end{array}$ \\
\hline $4 \mathrm{~A}$ & 4 Experienced limited connectivity. & It happened to have limited connectivity. \\
\hline $\mathbf{5 A}$ & $\begin{array}{l}\text { Observed limited quality service of } \\
\text { internet server. }\end{array}$ & $\begin{array}{l}\text { Limited quality service of server in the } \\
\text { school. }\end{array}$ \\
\hline 6A & 6 Experienced weak internet connection. & We have weak internet connection. \\
\hline 7A & $\begin{array}{l}7 \text { Failed to receive fast internet } \\
\text { connectivity. }\end{array}$ & $\begin{array}{l}\text { We have experienced failing to receive } \\
\text { internet data. }\end{array}$ \\
\hline $\mathbf{8 A}$ & $\begin{array}{l}8 \text { Needed huge demand of internet } \\
\text { connectivity. }\end{array}$ & $\begin{array}{l}\text { We need huge demand for high speed } \\
\text { internet connection. }\end{array}$ \\
\hline 9A & 9 Need reliable service provider. & $\begin{array}{l}\text { We need reliable internet service } \\
\text { provider. }\end{array}$ \\
\hline 10A & $\begin{array}{l}\mathbf{1 0} \text { Experienced temporary congestion } \\
\text { that leads to internet connection } \\
\text { problems. }\end{array}$ & $\begin{array}{l}\text { We experienced temporary congestion at } \\
\text { times leading to connection problems. }\end{array}$ \\
\hline 11A & $\begin{array}{l}11 \text { Experienced inconsistent internet } \\
\text { connectivity. }\end{array}$ & $\begin{array}{l}\text { We have inconsistent internet } \\
\text { connectivity. }\end{array}$ \\
\hline 12A & $\begin{array}{l}12 \text { Not reliable internet service provider } \\
\text { in the school }\end{array}$ & $\begin{array}{l}\text { Not reliable internet service provider in } \\
\text { the school. }\end{array}$ \\
\hline 13A & $\begin{array}{l}13 \text { Experienced failing internet } \\
\text { connection. }\end{array}$ & $\begin{array}{l}\text { Failing internet connectivity in the } \\
\text { school. }\end{array}$ \\
\hline 14A & $\begin{array}{l}14 \text { Experienced inconsistent internet } \\
\text { connectivity in the school. }\end{array}$ & $\begin{array}{l}\text { Inconsistent internet connectivity in the } \\
\text { school. }\end{array}$ \\
\hline 15A & $\begin{array}{l}15 \text { It has a weak quality of service } \\
\text { connectivity in the school. }\end{array}$ & $\begin{array}{l}\text { Weak quality of service connectivity in } \\
\text { the school. }\end{array}$ \\
\hline 16A & $\begin{array}{l}16 \text { It has poor connectivity of internet } \\
\text { service provider. }\end{array}$ & $\begin{array}{l}\text { Poor connectivity of internet service in } \\
\text { the school. }\end{array}$ \\
\hline
\end{tabular}




\begin{tabular}{|c|c|c|}
\hline 1B & $\begin{array}{l}1 \text { The school needs additional functional } \\
\text { computer. }\end{array}$ & $\begin{array}{l}\text { Additional functional computer in the } \\
\text { school. }\end{array}$ \\
\hline 2B & 2 Needs more functional computers. & $\begin{array}{l}\text { The school need more functional } \\
\text { computers. }\end{array}$ \\
\hline 3B & $\begin{array}{l}3 \text { The school should maintain a safe and } \\
\text { functional computer laboratory. }\end{array}$ & $\begin{array}{l}\text { The school should have safe computer } \\
\text { laboratory. }\end{array}$ \\
\hline 4B & 4 Consider the student-computer ratio. & $\begin{array}{l}\text { The school need to consider the ratio of } \\
\text { the computers. }\end{array}$ \\
\hline 5B & $\begin{array}{l}5 \text { Takes care of the computer in the } \\
\text { school. }\end{array}$ & $\begin{array}{l}\text { We need to take good care of the } \\
\text { computer. }\end{array}$ \\
\hline 6B & $\begin{array}{l}6 \text { Assigned each student to take care of } \\
\text { each computer. }\end{array}$ & $\begin{array}{l}\text { We need to assigned computers to each } \\
\text { student. }\end{array}$ \\
\hline 7B & $\begin{array}{l}7 \text { There should be proper tracking of } \\
\text { computers. }\end{array}$ & $\begin{array}{l}\text { We need to have proper tracking of } \\
\text { computer. }\end{array}$ \\
\hline $\mathbf{8 B}$ & $\begin{array}{l}8 \text { The activities of the platform should } \\
\text { be already in the functional computer. }\end{array}$ & $\begin{array}{l}\text { We need to input the activities in the } \\
\text { computer. }\end{array}$ \\
\hline 9B & $\begin{array}{l}9 \text { Availability of the discussions in the } \\
\text { computer. }\end{array}$ & $\begin{array}{l}\text { The discussion should be available in the } \\
\text { computer. }\end{array}$ \\
\hline 10B & $\begin{array}{l}10 \text { All activities in the platforms should } \\
\text { be in the computer. }\end{array}$ & $\begin{array}{l}\text { Inputs of the platforms should be in the } \\
\text { computer. }\end{array}$ \\
\hline 11B & $\begin{array}{l}11 \text { Problems of the availability of the } \\
\text { computer should be considered. }\end{array}$ & $\begin{array}{l}\text { The students should have no problem on } \\
\text { computer availability. }\end{array}$ \\
\hline 12B & $\begin{array}{l}12 \text { Distribution of computer to the } \\
\text { teachers for the platforms. }\end{array}$ & $\begin{array}{l}\text { The teachers should have each computer } \\
\text { for the platform. }\end{array}$ \\
\hline 13B & $\begin{array}{l}13 \text { Computer laboratory should be } \\
\text { considered. }\end{array}$ & $\begin{array}{l}\text { The availability of functional computer } \\
\text { laboratory. }\end{array}$ \\
\hline 14B & $\begin{array}{l}14 \text { Functional computer should be } \\
\text { available to the students. }\end{array}$ & $\begin{array}{l}\text { The availability of functional computer } \\
\text { for the students. }\end{array}$ \\
\hline 15B & $\begin{array}{l}15 \text { Issue functional computer to the } \\
\text { teachers for the platforms. }\end{array}$ & $\begin{array}{l}\text { The teacher should have functional } \\
\text { computer anytime needed. }\end{array}$ \\
\hline 16B & $\begin{array}{l}16 \text { Consider the computer availability } \\
\text { and students' ratio. }\end{array}$ & $\begin{array}{l}\text { The students' ratio on computer } \\
\text { availability should be considered. }\end{array}$ \\
\hline $1 \mathrm{C}$ & 1 Hired IT in-charge. & The school should have skilled IT. \\
\hline 2C & $\begin{array}{l}2 \text { Skilled IT for platform trouble } \\
\text { shooting of computers. }\end{array}$ & $\begin{array}{l}\text { Expert IT for trouble shooting of } \\
\text { computer. }\end{array}$ \\
\hline 3C & $\begin{array}{l}3 \text { The school should have IT in the } \\
\text { computer laboratory. }\end{array}$ & There should have IT in the school. \\
\hline $4 \mathrm{C}$ & $\begin{array}{l}4 \text { Availability of IT in the school for the } \\
\text { academic platforms. }\end{array}$ & IT assistance for the program. \\
\hline 5C & $\begin{array}{l}5 \text { School should have IT in-charge in the } \\
\text { school. }\end{array}$ & IT in-charge in the computer laboratory. \\
\hline 6C & $\begin{array}{l}6 \text { Computer laboratory availability in the } \\
\text { school. }\end{array}$ & Availability of computer laboratory. \\
\hline 7C & $\begin{array}{l}7 \text { There should be IT assistance in the } \\
\text { program implementation. }\end{array}$ & $\begin{array}{l}\text { IT Assistance for the program } \\
\text { implementation. }\end{array}$ \\
\hline 8C & 8 Availability of computer experts. & School should have computer expert. \\
\hline 9C & $\begin{array}{l}9 \text { Computer expert in the school should } \\
\text { be considered. }\end{array}$ & $\begin{array}{l}\text { Considered the availability of computer } \\
\text { expert. }\end{array}$ \\
\hline
\end{tabular}




\begin{tabular}{lll}
\hline 10C & $\begin{array}{l}\text { 10 The school should have IT expert for } \\
\text { the academic platforms. }\end{array}$ & The presence of the IT expert. \\
\hline 11C & 11 School should have IT expert. & Hired IT expert. \\
\hline 12C & $\begin{array}{l}\text { 12 Computer In-charge in the school. } \\
\text { 13C }\end{array}$ & $\begin{array}{l}\text { Availability of computer in-charge. } \\
\text { laboratory. }\end{array}$ \\
\hline 14C & $\begin{array}{l}\text { 14 Availability of computer expert in the } \\
\text { school computer laboratory. }\end{array}$ & The presence of computer expert. \\
\hline 15C & $\begin{array}{l}\text { 15 Computer laboratory should have IT } \\
\text { expert for the academic platforms. }\end{array}$ & $\begin{array}{l}\text { The presence of IT expert in computer } \\
\text { laboratory. }\end{array}$ \\
\hline 16C & $\begin{array}{l}\text { 16 The school should have IT expert for } \\
\text { the academic platforms. }\end{array}$ & $\begin{array}{l}\text { The presence of IT expert for the } \\
\text { platform. }\end{array}$ \\
\hline
\end{tabular}

Table 4.3. Themes Based on the Concepts Constructed from Problems Encountered by the Respondents in the Implementation of DICP

\begin{tabular}{|c|c|c|}
\hline $\begin{array}{l}\text { REFERENCE } \\
\text { NUMBERS }\end{array}$ & CONCEPTS & THEMES \\
\hline $\mathbf{1 A}$ & $\begin{array}{l}\text { The school experienced poor connectivity } \\
\text { encounter issues. }\end{array}$ & \multirow{14}{*}{$\begin{array}{l}\text { Challenging Experiences of the } \\
\text { Respondents }\end{array}$} \\
\hline $2 \mathrm{~A}$ & $\begin{array}{l}\text { We experienced problem on inconsistent } \\
\text { connectivity. }\end{array}$ & \\
\hline $\mathbf{3 A}$ & $\begin{array}{l}\text { The teachers and students experienced } \\
\text { noticeable delays of usability. }\end{array}$ & \\
\hline 4A & It happened to have limited connectivity. & \\
\hline 5A & $\begin{array}{l}\text { Limited quality service of server in the } \\
\text { school. }\end{array}$ & \\
\hline 6A & We have weak internet connection. & \\
\hline 7A & $\begin{array}{l}\text { We have experienced failing to receive } \\
\text { internet data. }\end{array}$ & \\
\hline $\mathbf{8 A}$ & $\begin{array}{l}\text { We need huge demand for high speed } \\
\text { internet connection. }\end{array}$ & \\
\hline 9A & We need reliable internet service provider. & \\
\hline 10A & $\begin{array}{l}\text { We experienced temporary congestion at } \\
\text { times leading to connection problems. }\end{array}$ & \\
\hline 11A & We have inconsistent internet connectivity. & \\
\hline $12 \mathrm{~A}$ & $\begin{array}{l}\text { Not reliable internet service provider in the } \\
\text { school. }\end{array}$ & \\
\hline 13A & Failing internet connectivity in the school. & \\
\hline 14A & $\begin{array}{l}\text { Inconsistent internet connectivity in the } \\
\text { school. }\end{array}$ & \\
\hline
\end{tabular}




\begin{tabular}{|c|c|c|}
\hline 15A & $\begin{array}{l}\text { Weak quality of service connectivity in the } \\
\text { school. }\end{array}$ & \multirow{7}{*}{$\begin{array}{l}\text { Difficulties Encountered of the } \\
\text { Respondents }\end{array}$} \\
\hline 16A & $\begin{array}{l}\text { Poor connectivity of internet service in the } \\
\text { school. }\end{array}$ & \\
\hline 1B & $\begin{array}{l}\text { Additional functional computer in the } \\
\text { school. }\end{array}$ & \\
\hline 2B & $\begin{array}{l}\text { The school need more functional } \\
\text { computers. }\end{array}$ & \\
\hline 3B & $\begin{array}{l}\text { The school should have safe computer } \\
\text { laboratory. }\end{array}$ & \\
\hline 4B & $\begin{array}{l}\text { The school need to consider the ratio of the } \\
\text { computers. }\end{array}$ & \\
\hline 5B & We need to take good care the computer. & \\
\hline 6B & We need to assigned computer each student. & \\
\hline 7B & $\begin{array}{l}\text { We need to have proper tracking of } \\
\text { computer. }\end{array}$ & \\
\hline 8B & $\begin{array}{l}\text { We need to input the activities in the } \\
\text { computer. }\end{array}$ & \\
\hline 9B & $\begin{array}{l}\text { The discussion should be available in the } \\
\text { computer. }\end{array}$ & \\
\hline 10B & $\begin{array}{l}\text { Inputs of the platforms should be in the } \\
\text { computer. }\end{array}$ & \\
\hline 11B & $\begin{array}{l}\text { The students should have no problem on } \\
\text { computer availability. }\end{array}$ & \\
\hline 12B & $\begin{array}{l}\text { The teachers should have each computer for } \\
\text { the platform. }\end{array}$ & \\
\hline 13B & $\begin{array}{l}\text { The availability of functional computer } \\
\text { laboratory. }\end{array}$ & \\
\hline 14B & $\begin{array}{l}\text { The availability of functional computer for } \\
\text { the students. }\end{array}$ & \\
\hline 15B & $\begin{array}{l}\text { The teacher should have functional } \\
\text { computer anytime needed. }\end{array}$ & \\
\hline 16B & $\begin{array}{l}\text { The students' ratio on computer availability } \\
\text { should be considered. }\end{array}$ & \\
\hline $1 \mathrm{C}$ & The school should have skilled IT. & \multirow{6}{*}{$\begin{array}{l}\text { Asking Personal and Professional } \\
\text { Help on Technical Assistance }\end{array}$} \\
\hline $2 \mathrm{C}$ & Expert IT for troubleshooting of computer. & \\
\hline 3C & There should have IT in the school. & \\
\hline $4 \mathrm{C}$ & IT assistance for the program. & \\
\hline $5 \mathrm{C}$ & IT in-charge in the computer laboratory. & \\
\hline 6C & Availability of computer laboratory. & \\
\hline
\end{tabular}




\begin{tabular}{|c|c|}
\hline $7 \mathrm{C}$ & $\begin{array}{l}\text { IT Assistance for the program } \\
\text { implementation. }\end{array}$ \\
\hline 8C & School should have computer expert. \\
\hline 9C & $\begin{array}{l}\text { Considered the availability of computer } \\
\text { expert. }\end{array}$ \\
\hline 10C & The presence of the IT expert. \\
\hline 11C & Hired IT expert. \\
\hline $12 \mathrm{C}$ & Availability of computer in-charge. \\
\hline 13C & Functional computer laboratory. \\
\hline 14C & The presence of computer expert. \\
\hline 15C & $\begin{array}{l}\text { The presence of IT expert in computer } \\
\text { laboratory. }\end{array}$ \\
\hline 16C & The presence of IT expert for the platform \\
\hline
\end{tabular}

These results revealed that there were challenges and difficulties experienced by the respondents particularly in terms of speed of internet connectivity and availability of functional computers for the DICP implementation and the Edmodo platform. Additionally, the respondents requested for professional or technical assistance from IT experts.

Moreover, the results revealed that even if the DICP implementation was effective, there still were challenges and complications encountered along the process. And, if unresolved, it will provide a challenge to fully utilize the Edmodo platform in teaching lessons in Social Studies.

Problem 5. What are the problems encountered in the Edmodo utilization?

Previous results showed that the utilization of the Edmodo platform proved its effectiveness in teaching lessons in Social Studies. However, complications could still be expected in its usage. The corresponding tables below show the categories of concepts of the respondents' problems encountered in the Edmodo utilization, the concepts derived from the respondents' transcripts on their problems encountered in the Edmodo utilization, and the themes based on the concepts constructed from the respondents' problems encountered in the Edmodo utilization.

Table 5.1. Categories of the Concepts of the Problems Encountered by the Respondents in the EDMODO Utilization.

\begin{tabular}{cll}
\hline $\begin{array}{c}\text { REFERENCE } \\
\text { NUMBERS }\end{array}$ & \multicolumn{1}{c}{ CONCEPTS } & \multicolumn{1}{c}{ CATEGORIES } \\
\hline 1A & $\begin{array}{c}\text { Teachers should be trained on the } \\
\text { EDMODO Platform. }\end{array}$ & $\begin{array}{l}\text { Teachers Competencies, Expertise and } \\
\text { Skills }\end{array}$ \\
\hline 1B & Trained monitoring in-charge. & Means of Monitoring and Evaluation \\
\hline 1C & Giving unlimited time. & $\begin{array}{l}\text { Reflection on assessment of } \\
\text { Implementation }\end{array}$ \\
\hline
\end{tabular}




\begin{tabular}{|c|c|c|}
\hline $\mathbf{2 A}$ & $\begin{array}{l}\text { Teachers should be familiar on the } \\
\text { feature of the platform. }\end{array}$ & $\begin{array}{l}\text { Teachers Competencies, Expertise and } \\
\text { Skills }\end{array}$ \\
\hline 2B & $\begin{array}{l}\text { Online monitoring should be } \\
\text { implemented. }\end{array}$ & Means of Monitoring and Evaluation \\
\hline $2 \mathrm{C}$ & Uncontrolled time for the activities. & $\begin{array}{l}\text { Reflection on assessment of } \\
\text { Implementation }\end{array}$ \\
\hline $\mathbf{3 A}$ & $\begin{array}{l}\text { Teachers' expertise on the formal } \\
\text { assessment of the platform. }\end{array}$ & $\begin{array}{l}\text { Teachers Competencies, Expertise and } \\
\text { Skills }\end{array}$ \\
\hline 3B & $\begin{array}{l}\text { Target time activities should be } \\
\text { followed. }\end{array}$ & Means of Monitoring and Evaluation \\
\hline 3C & $\begin{array}{l}\text { They can also have leisure time while } \\
\text { learning. }\end{array}$ & $\begin{array}{l}\text { Reflection on assessment of } \\
\text { Implementation }\end{array}$ \\
\hline 4A & $\begin{array}{l}\text { Teachers' expertise on calendar of } \\
\text { activities posting. }\end{array}$ & $\begin{array}{l}\text { Teachers Competencies, Expertise and } \\
\text { Skills }\end{array}$ \\
\hline 4B & $\begin{array}{l}\text { Online monitoring should be } \\
\text { considered. }\end{array}$ & Means of Monitoring and Evaluation \\
\hline $4 \mathrm{C}$ & $\begin{array}{l}\text { Claim to have learning with pleasure } \\
\text { reason. }\end{array}$ & $\begin{array}{l}\text { Reflection on assessment of } \\
\text { Implementation }\end{array}$ \\
\hline $\mathbf{5 A}$ & $\begin{array}{l}\text { Trained on the integration of the } \\
\text { Google features. }\end{array}$ & $\begin{array}{l}\text { Teachers Competencies, Expertise and } \\
\text { Skills }\end{array}$ \\
\hline 5B & $\begin{array}{l}\text { Schedule of monitoring should be } \\
\text { considered. }\end{array}$ & Means of Monitoring and Evaluation \\
\hline $5 C$ & $\begin{array}{l}\text { Learning simply as well as being } \\
\text { motivated. }\end{array}$ & $\begin{array}{l}\text { Reflection on assessment of } \\
\text { Implementation }\end{array}$ \\
\hline 6A & Familiarity of community forums. & $\begin{array}{l}\text { Teachers Competencies, Expertise and } \\
\text { Skills }\end{array}$ \\
\hline 6B & Daily monitoring of the output. & Means of Monitoring and Evaluation \\
\hline 6C & Availability of computer gadgets. & $\begin{array}{l}\text { Reflection on assessment of } \\
\text { Implementation }\end{array}$ \\
\hline 7A & Skills on online assessment features. & $\begin{array}{l}\text { Teachers Competencies, Expertise and } \\
\text { Skills }\end{array}$ \\
\hline 7B & Checklist recording of the tasks. & Means of Monitoring and Evaluation \\
\hline 7C & $\begin{array}{l}\text { Difficulties on low computer user of } \\
\text { computer. }\end{array}$ & $\begin{array}{l}\text { Reflection on assessment of } \\
\text { Implementation }\end{array}$ \\
\hline $\mathbf{8 A}$ & Awareness on online assessment. & $\begin{array}{l}\text { Teachers Competencies, Expertise and } \\
\text { Skills }\end{array}$ \\
\hline 8B & $\begin{array}{l}\text { Teachers posted activities are } \\
\text { important. }\end{array}$ & Means of Monitoring and Evaluation \\
\hline 8C & $\begin{array}{l}\text { Computer connections should be } \\
\text { considered. }\end{array}$ & $\begin{array}{l}\text { Reflection on assessment of } \\
\text { Implementation }\end{array}$ \\
\hline 9A & Trained on the platform features. & $\begin{array}{l}\text { Teachers Competencies, Expertise and } \\
\text { Skills }\end{array}$ \\
\hline 9B & $\begin{array}{l}\text { Advance posting of tasks should be } \\
\text { considered. }\end{array}$ & Means of Monitoring and Evaluation \\
\hline 9C & $\begin{array}{l}\text { Feedbacking of the teachers are } \\
\text { important feature. }\end{array}$ & $\begin{array}{l}\text { Reflection on assessment of } \\
\text { Implementation }\end{array}$ \\
\hline
\end{tabular}




\begin{tabular}{|c|c|c|}
\hline $\mathbf{1 0 A}$ & Quality personalized learning. & $\begin{array}{l}\text { Teachers Competencies, Expertise and } \\
\text { Skills }\end{array}$ \\
\hline 10B & Technological evaluation is important. & Means of Monitoring and Evaluation \\
\hline 10C & $\begin{array}{l}\text { Limited knowledge of the platform } \\
\text { could be a problem. }\end{array}$ & $\begin{array}{l}\text { Reflection on assessment of } \\
\text { Implementation }\end{array}$ \\
\hline 11A & Expertise on the online sessions. & $\begin{array}{l}\text { Teachers Competencies, Expertise and } \\
\text { Skills }\end{array}$ \\
\hline 11B & $\begin{array}{l}\text { Adequate training of the monitoring } \\
\text { person. }\end{array}$ & Means of Monitoring and Evaluation \\
\hline 11C & $\begin{array}{l}\text { Choice of technology should be } \\
\text { considered. }\end{array}$ & $\begin{array}{l}\text { Reflection on assessment of } \\
\text { Implementation }\end{array}$ \\
\hline $12 \mathrm{~A}$ & Trained on offline activities. & $\begin{array}{l}\text { Teachers Competencies, Expertise and } \\
\text { Skills }\end{array}$ \\
\hline 12B & Infused technology step by step. & Means of Monitoring and Evaluation \\
\hline 12C & $\begin{array}{l}\text { Technology chosen highlights the } \\
\text { crucial issues of the platform. }\end{array}$ & $\begin{array}{l}\text { Reflection on assessment of } \\
\text { Implementation }\end{array}$ \\
\hline 13A & $\begin{array}{l}\text { Provided competencies of teachers on } \\
\text { learning preferences. }\end{array}$ & $\begin{array}{l}\text { Teachers Competencies, Expertise and } \\
\text { Skills }\end{array}$ \\
\hline 13B & $\begin{array}{l}\text { Features of the platform should be well } \\
\text { informed to the monitoring person. }\end{array}$ & Means of Monitoring and Evaluation \\
\hline 13C & Confusion of the platform features. & $\begin{array}{l}\text { Reflection on assessment of } \\
\text { Implementation }\end{array}$ \\
\hline 14A & $\begin{array}{l}\text { Observed skills on cognitive } \\
\text { engagement. }\end{array}$ & $\begin{array}{l}\text { Teachers Competencies, Expertise and } \\
\text { Skills }\end{array}$ \\
\hline 14B & $\begin{array}{l}\text { Introduce various media access for } \\
\text { monitoring. }\end{array}$ & Means of Monitoring and Evaluation \\
\hline 14C & $\begin{array}{l}\text { Adequate training should be } \\
\text { considered. }\end{array}$ & $\begin{array}{l}\text { Reflection on assessment of } \\
\text { Implementation }\end{array}$ \\
\hline 15A & Utilized platform on academic matters. & $\begin{array}{l}\text { Teachers Competencies, Expertise and } \\
\text { Skills }\end{array}$ \\
\hline 15B & Various accesses for assessment. & Means of Monitoring and Evaluation \\
\hline 15C & $\begin{array}{l}\text { Technology familiarity should be } \\
\text { prioritized. }\end{array}$ & $\begin{array}{l}\text { Reflection on assessment of } \\
\text { Implementation }\end{array}$ \\
\hline 16A & Skills on learner-content interaction. & $\begin{array}{l}\text { Teachers Competencies, Expertise and } \\
\text { Skills }\end{array}$ \\
\hline $16 B$ & $\begin{array}{l}\text { Availability of trained person to in- } \\
\text { charge the monitoring and evaluation } \\
\text { of the platform. }\end{array}$ & Means of Monitoring and Evaluation \\
\hline $16 \mathrm{C}$ & $\begin{array}{l}\text { Training of the technology especially } \\
\text { the platform features. }\end{array}$ & $\begin{array}{l}\text { Reflection on assessment of } \\
\text { Implementation }\end{array}$ \\
\hline
\end{tabular}


Table 5.2. Concepts Derived from the Transcripts on the Problems Encountered by the Respondents in the EDMODO Utilization.

\section{REFERENCE NUMBERS}

\begin{tabular}{|c|c|c|}
\hline $\mathbf{1 A}$ & $\begin{array}{l}\text { Need of technical training for the } \\
\text { EDMODO platforms. }\end{array}$ & $\begin{array}{l}\text { Teachers should be trained on the } \\
\text { EDMODO Platform. }\end{array}$ \\
\hline $\mathbf{2 A}$ & $\begin{array}{l}\text { Familiarity of the features of the } \\
\text { platforms should be considered. }\end{array}$ & $\begin{array}{l}\text { Teachers should be familiar on the } \\
\text { feature of the platform. }\end{array}$ \\
\hline $\mathbf{3 A}$ & $\begin{array}{l}\text { Trained experts on the assessment of } \\
\text { the EDMODO platforms. }\end{array}$ & $\begin{array}{l}\text { Teachers expertise on the formal } \\
\text { assessment of the platform. }\end{array}$ \\
\hline 4A & $\begin{array}{l}\text { Posting of the calendar of the } \\
\text { activities of the students should be } \\
\text { posted. }\end{array}$ & $\begin{array}{l}\text { Teachers expertise on calendar of activities } \\
\text { posting. }\end{array}$ \\
\hline $\mathbf{5 A}$ & $\begin{array}{l}\text { Trained teachers for the technological } \\
\text { features of the EDMODO platforms. }\end{array}$ & $\begin{array}{l}\text { Trained on the integration of the Google } \\
\text { features. }\end{array}$ \\
\hline 6A & $\begin{array}{l}\text { Familiarity of the platforms for the } \\
\text { community forums. }\end{array}$ & Familiarity of community forums. \\
\hline 7A & $\begin{array}{l}\text { Trained skills on the features for } \\
\text { online assessment. }\end{array}$ & Skills on online assessment features. \\
\hline $\mathbf{8 A}$ & $\begin{array}{l}\text { Steps on Online assessment should be } \\
\text { discussed properly. }\end{array}$ & Awareness on online assessment. \\
\hline 9A & $\begin{array}{l}\text { Trained the teachers on the features of } \\
\text { EDMODO platforms. }\end{array}$ & Trained on the platform features. \\
\hline 10A & $\begin{array}{l}\text { Consider quality personalized } \\
\text { learning. }\end{array}$ & Quality personalized learning. \\
\hline 11A & $\begin{array}{l}\text { Trained to be expert on the online } \\
\text { sessions. }\end{array}$ & Expertise on the online sessions. \\
\hline 12A & $\begin{array}{l}\text { Trained also on offline activities of the } \\
\text { EDMODO platforms. }\end{array}$ & Trained on offline activities. \\
\hline 13A & $\begin{array}{l}\text { Provide trainings on teachers learning } \\
\text { preferences. }\end{array}$ & $\begin{array}{l}\text { Provided competencies of teachers on } \\
\text { learning preferrences. }\end{array}$ \\
\hline 14A & $\begin{array}{l}\text { Observance on the cognitive } \\
\text { engagement skills. }\end{array}$ & Observed skills on cognitive engagement. \\
\hline 15A & $\begin{array}{l}\text { There should be utilization of } \\
\text { platforms academic matters. }\end{array}$ & Utilized platform on academic matters. \\
\hline 16A & $\begin{array}{l}\text { Trained teachers on skills of learner - } \\
\text { content interactions. }\end{array}$ & Skills on learner-content interaction. \\
\hline 1B & $\begin{array}{l}\text { Training of EDMODO in-charge is } \\
\text { important. }\end{array}$ & Trained monitoring incharge. \\
\hline 2B & $\begin{array}{l}\text { Monitoring on online class should be } \\
\text { implemented. }\end{array}$ & Online monitoring should be implemented. \\
\hline 3B & $\begin{array}{l}\text { Activities of the EDMODO platforms } \\
\text { should be followed. }\end{array}$ & Target time activities should be followed. \\
\hline 4B & Monitoring the platform is advisable. & Online monitoring should be considered. \\
\hline 5B & $\begin{array}{l}\text { Time schedule for monitoring should } \\
\text { be considered. }\end{array}$ & $\begin{array}{l}\text { Schedule of monitoring should be } \\
\text { considered. }\end{array}$ \\
\hline
\end{tabular}


Daily monitoring of the output.

7B Monitoring checklist of the task is

Checklist recording of the tasks.

advisable.

8B Posting of activities for the platforms Teachers posted activities are important. is a great help.

9B Tasks should be posted ahead. Advance posting of tasks should be considered.

10B The platform should be evaluated Technological evaluation is important. especially the facilities.

11B Trained person to monitor the Adequate training of the monitoring EDMODO platform. person.

12B Introduced and infused the process of Infused technology step by step. the platform step by step.

13B The monitoring person should be $\quad$ Features of the platform should be well informed on the features of the informed to the monitoring person. platform.

\begin{tabular}{|c|c|c|}
\hline 14B & $\begin{array}{l}\text { Access on monitoring should be } \\
\text { introduced to the trained monitor. }\end{array}$ & $\begin{array}{l}\text { Introduce various media access for } \\
\text { monitoring. }\end{array}$ \\
\hline 15B & $\begin{array}{l}\text { Access on monitoring of assessment } \\
\text { should be given to the trained monitor. }\end{array}$ & Various accesses for assessment. \\
\hline $16 B$ & $\begin{array}{l}\text { There should be trained person to } \\
\text { monitor and evaluate the platform. }\end{array}$ & $\begin{array}{l}\text { Availability of trained person to in-charge } \\
\text { the monitoring and evaluation of the } \\
\text { platform. }\end{array}$ \\
\hline $1 \mathrm{C}$ & $\begin{array}{l}\text { Time schedule and time frame should } \\
\text { be given to the learners. }\end{array}$ & Giving unlimited time. \\
\hline $2 \mathrm{C}$ & $\begin{array}{l}\text { The activities should be given time } \\
\text { frame. }\end{array}$ & Uncontrolled time for the activities. \\
\hline $3 \mathrm{C}$ & $\begin{array}{l}\text { Separate the leisure time to academic } \\
\text { learning. }\end{array}$ & $\begin{array}{l}\text { They can also have leisure time while } \\
\text { learning. }\end{array}$ \\
\hline $4 \mathrm{C}$ & $\begin{array}{l}\text { Academic learning online is also } \\
\text { pleasurable. }\end{array}$ & $\begin{array}{l}\text { Claim to have learning with pleasure } \\
\text { reason. }\end{array}$ \\
\hline $5 \mathrm{C}$ & Be motivated in online learning. & $\begin{array}{l}\text { Learning simply as well as being } \\
\text { motivated. }\end{array}$ \\
\hline 6C & $\begin{array}{l}\text { Consider the availability of online } \\
\text { computer gadgets. }\end{array}$ & Availability of computer gadgets. \\
\hline 7C & $\begin{array}{l}\text { Low computer user expertise which } \\
\text { made it difficult to the user. }\end{array}$ & $\begin{array}{l}\text { Difficulties on low computer user of } \\
\text { computer. }\end{array}$ \\
\hline 8C & The internet connectivity is important. & $\begin{array}{l}\text { Computer connections should be } \\
\text { considered. }\end{array}$ \\
\hline 9C & $\begin{array}{l}\text { It is important that the teacher will } \\
\text { give feedbacks on the platform } \\
\text { features. }\end{array}$ & $\begin{array}{l}\text { Feedbacking of the teachers are important } \\
\text { feature. }\end{array}$ \\
\hline 10C & $\begin{array}{l}\text { There will be problem if user has } \\
\text { limited knowledge of the platform. }\end{array}$ & $\begin{array}{l}\text { Limited knowledge of the platform could } \\
\text { be a problem. }\end{array}$ \\
\hline $11 \mathrm{C}$ & $\begin{array}{l}\text { Technological gadgets and its choice } \\
\text { should be considered. }\end{array}$ & $\begin{array}{l}\text { Choice of technology should be } \\
\text { considered. }\end{array}$ \\
\hline $12 \mathrm{C}$ & $\begin{array}{l}\text { Choice of technology is a crucial issue } \\
\text { of the platform. }\end{array}$ & $\begin{array}{l}\text { Technology chosen highlights the crucial } \\
\text { issues of the platform. }\end{array}$ \\
\hline
\end{tabular}




\begin{tabular}{lll}
\hline 13C & $\begin{array}{l}\text { The features of the platform should be } \\
\text { discussed well for no confusions. }\end{array}$ & Confusion of the platform features. \\
\hline 14C & $\begin{array}{l}\text { Training should be considered } \\
\text { adequately. }\end{array}$ & Adequate training should be considered. \\
\hline 15C & $\begin{array}{l}\text { Being familiar of technology for the } \\
\text { platforms should be given priority. } \\
\text { Trained the users on the features of } \\
\text { the platforms. }\end{array}$ & $\begin{array}{l}\text { Technology familiarity should be } \\
\text { prioritized. } \\
\text { Training of the technology especially the } \\
\text { platform features. }\end{array}$ \\
\hline
\end{tabular}

Table 5.3. Themes Based on the Concepts Constructed from the Problems Encountered of the Respondents in the EDMODO Utilization

REFERENCE NUMBERS

\begin{tabular}{|c|c|}
\hline $\mathbf{1 A}$ & $\begin{array}{l}\text { Teachers should be trained on the EDMODO } \\
\text { Platform. }\end{array}$ \\
\hline $\mathbf{2 A}$ & $\begin{array}{l}\text { Teachers should be familiar on the feature of } \\
\text { the platform. }\end{array}$ \\
\hline $\mathbf{3 A}$ & $\begin{array}{l}\text { Teachers' expertise on the formal assessment } \\
\text { of the platform. }\end{array}$ \\
\hline $\mathbf{4 A}$ & $\begin{array}{l}\text { Teachers' expertise on calendar of activities } \\
\text { posting. }\end{array}$ \\
\hline $\mathbf{5 A}$ & $\begin{array}{l}\text { Trained on the integration of the Google } \\
\text { features. }\end{array}$ \\
\hline 6A & Familiarity of community forums. \\
\hline 7A & Skills on online assessment features. \\
\hline $\mathbf{8 A}$ & Awareness on online assessment. \\
\hline 9A & Trained on the platform features. \\
\hline 10A & Quality personalized learning. \\
\hline 11A & Expertise on the online sessions. \\
\hline 12A & Trained on offline activities. \\
\hline 13A & $\begin{array}{l}\text { Provided competencies of teachers on } \\
\text { learning preferences. }\end{array}$ \\
\hline $14 \mathrm{~A}$ & Observed skills on cognitive engagement. \\
\hline 15A & Jtilized platform on academic matters. \\
\hline
\end{tabular}

\begin{tabular}{|c|c|c|}
\hline 16A & Skills on learner-content interaction. & \\
\hline 1B & Trained monitoring in-charge. & \multirow{7}{*}{$\begin{array}{l}\text { Difficulties Encountered of the } \\
\text { Respondents }\end{array}$} \\
\hline $2 \mathbf{B}$ & Online monitoring should be implemented. & \\
\hline 3B & Target time activities should be followed. & \\
\hline 4B & Online monitoring should be considered. & \\
\hline 5B & $\begin{array}{l}\text { Schedule of monitoring should be } \\
\text { considered. }\end{array}$ & \\
\hline $6 B$ & Daily monitoring of the output. & \\
\hline 7B & Checklist recording of the tasks. & \\
\hline
\end{tabular}

\section{Challenging Experiences of the} Respondents

\section{CONCEPTS} pondents

\section{THEMES}


Teachers posted activities are important.

9B Advance posting of tasks should be considered.

10B Technological evaluation is important.

11B Adequate training of the monitoring person.

\begin{tabular}{|c|c|c|}
\hline 12B & Infused technology step by step. & \multirow{21}{*}{$\begin{array}{l}\text { Personal Reflection for } \\
\text { Technical Assistance }\end{array}$} \\
\hline 13B & $\begin{array}{l}\text { Features of the platform should be well } \\
\text { informed to the monitoring person. }\end{array}$ & \\
\hline 14B & $\begin{array}{l}\text { Introduce various media access for } \\
\text { monitoring. }\end{array}$ & \\
\hline 15B & Various accesses for assessment. & \\
\hline 16B & $\begin{array}{l}\text { Availability of trained person to in-charge } \\
\text { the monitoring and evaluation of the } \\
\text { platform. }\end{array}$ & \\
\hline $1 \mathrm{C}$ & Giving unlimited time. & \\
\hline $2 \mathrm{C}$ & Uncontrolled time for the activities. & \\
\hline 3C & $\begin{array}{l}\text { They can also have leisure time while } \\
\text { learning. }\end{array}$ & \\
\hline $4 \mathrm{C}$ & Claim to have learning with pleasure reason. & \\
\hline $5 \mathrm{C}$ & Learning simply as well as being motivated. & \\
\hline 6C & Availability of computer gadgets. & \\
\hline 7C & $\begin{array}{l}\text { Difficulties on low computer user of } \\
\text { computer. }\end{array}$ & \\
\hline 8C & Computer connections should be considered. & \\
\hline 9C & $\begin{array}{l}\text { Feedbacking of the teachers are important } \\
\text { feature. }\end{array}$ & \\
\hline 10C & $\begin{array}{l}\text { Limited knowledge of the platform could be } \\
\text { a problem. }\end{array}$ & \\
\hline 11C & Choice of technology should be considered. & \\
\hline 12C & $\begin{array}{l}\text { Technology chosen highlights the crucial } \\
\text { issues of the platform. }\end{array}$ & \\
\hline 13C & Confusion of the platform features. & \\
\hline 14C & Adequate training should be considered. & \\
\hline 15C & Technology familiarity should be prioritized. & \\
\hline 16C & $\begin{array}{l}\text { Training of the technology especially the } \\
\text { platform features. }\end{array}$ & \\
\hline
\end{tabular}

These results revealed that there were challenges and difficulties experienced by the respondents in terms of competencies, expertise and skills for the utilization of the Edmodo platform. Consequently, the respondents mainly requested for technical assistance as reflected on the assessment of the implementation for the proper monitoring and evaluation of the Edmodo platform.

Though the respondents were given training on the Edmodo platform and its utilization, with the results, they are still in need of technical assistance from the IT experts and the like to avoid or minimize complications in teaching lessons in Social Studies. 
Problem 6. What is the correlation between the use of the Edmodo platform in Social Studies classes and the implementation of the DICP n.50, s.2009?

The DICP is an avenue for the arrival of $21^{\text {st }}$ century educational tools to help deliver lessons to the new generation of learners. Also, it provides enhancement and new knowledge with regards to the various accessible platforms to help in the teaching-learning process, like Edmodo. The table below shows correlation coefficient and the significance level of relationship between the DICP n.50, s.2009, and the Edmodo platform.

Table 6. Correlation Coefficient and Significance of Relationship between the Use of Edmodo in the Social Studies Classes and the Implementation of DICP \# 50, 2009

DICP Indicators

Use of Edmodo in the Social Studies Classes

\begin{tabular}{lllll} 
& $\begin{array}{l}\text { Correlation } \\
\text { Coefficient }\end{array}$ & p-value & Decision & Interpretation \\
\hline Internet Connectivity & $0.342^{*}$ & 0.000 & Reject & Significant \\
\hline School Facilities & $0.336^{*}$ & 0.000 & Reject & Significant \\
\hline Computer Laboratories & $0.411^{*}$ & 0.000 & Reject & Significant \\
\hline Computer Hardware & $0.380^{*}$ & 0.000 & Reject & Significant \\
\hline Computer Software & $0.239^{*}$ & 0.000 & Reject & Significant \\
\hline Computer Student Ratio & $0.393^{*}$ & 0.003 & Reject & Significant \\
\hline Overall DICP Implementation & 0.498 & 0.000 & Reject & Significant
\end{tabular}

Legend: .81-1.00-Very High; 0.61-.080- High; 0.41-.60-Moderate;0.21-.40 Low; 0.0-0.20 Very Low

*Significant at 0.05 level

As shown by the results, the computer laboratories indicator $(0.411, \mathrm{p}<0.05)$ has the highest correlation, and the computer software indicator with the lowest correlation $(0.239, \mathrm{p}<0.05)$. In addition, the rest of the indicators have positive correlation to the use of Edmodo in teaching Social Studies: first, the computer hardware indicator $(0.380, \mathrm{p}<0.05)$; second, the internet connectivity indicator $(0.380, \mathrm{p}<0.05)$; third, the school facilities indicator $(0.336, \mathrm{p}<0.05)$; and, the computer software indicator $(0.239, \mathrm{p}<0.05)$.

The overall DICP implementation result was positively and moderately correlated to the use of Edmodo in teaching lessons in Social Studies. Moreover, the results indicated that all the indicators of the DICP implementation are significantly correlated to the usage of EDMODO platform. This means that the use of Edmodo in teaching lessons in Social Studies classes positively affect the implementation of DICP n.50, s.2009. 


\section{Conclusions}

Based on the findings of the study, these conclusions were drawn:

1. It was indicated that all domains of the DICP implementation are significantly correlated to the usage of the Edmodo platform in teaching lessons in Social Studies.

2. The respondents have a competency level of very satisfactory on the implementation of the Edmodo platform in their respective Social Studies classes.

3. The students, after being exposed to the Edmodo platform, have a higher achievement test in Social Studies as compared to not being exposed to the platform.

4. There were challenges and difficulties experienced by the respondents in terms of the speed of internet connectivity and availability of functional computers for the DICP implementation. The availability of IT experts, and the like, in their respective schools was requested.

5. There were challenges and difficulties experience by the respondents in terms of competencies, expertise and skills for the utilization of the Edmodo platform. The availability of IT experts, and the like, in their respective schools was requested.

6. All indicators of the DICP implementation were significantly correlated to the usage of the Edmodo platform in teaching lessons in Social Studies.

\section{Recommendations}

In the light of the conclusions in this study, the following recommendations are presented:

Department of Education. Envision and prioritize budget on the School Computer Laboratory and Facilities to fully realize the effectiveness of the DICP implementation.

Gingoog City Division. For guidance of teachers and administrators, the Division Office may initiate activities that will refresh and enhance them of the technological skills needed in the new normal under the $21^{\text {st }}$ century.

School Administrators. To improve and to develop appropriate technological skills in the new normal, school administrators may invite experts to conduct activities that will enhance and will introduce teachers' to new and improved technological skills.

Teachers. For professional development, school heads may encourage its teachers to invest in education by taking up degree programs in graduate studies.

Future Researchers. Continue the study of the DICP implementation and Edmodo platform in teaching lessons in other subject areas or grade levels.

Parents. Be observant and aware of the DICP implementation and the Edmodo platform utilization.

Students. Attend enhancement programs on technological skills in preparation for online learning. 


\section{References}

Anderson, L,W. Kruthwohl, DR., Airisian PW.Cruikshank, KA;Mayer, R.E., Pintrich, P.R, $\quad$ Raths $\quad$ J., Wittrock, M.C.(2000). A Taxonomy for Learning, and Assessment: A revision of Blooms Taxonomy of Educational objectives. New York: Pearson, Allyn and Bacon.

Carolan, F., \& Kyppö, A. (2015). Teaching process writing in an online environment Voices of pedagogical/development-Expanding, enhancing and exploring higher education learning, 13.

Cruz, Maribel B. \& Cruz, Shannen B. (2013). The Use of Internet-Based Social Media as a Tool in Enhancing Learning Experiences in Biological Sciences, New Era University, Philippines.

Dogoriti, E. and Pange. J., Instruction design for a "social" classroom: Edmodo and Twitter in the foreign language classroom, ICICTE proceeding, 2014, pp. 154-165.

Enriquez, A. M., Students' perceptions on the effectiveness of the use of Edmodo as supplementary tool for learning. Presented at the DLSU Research Congress 2014, De La Salle University, Manila, Philippines, March, 2014, p.5. 